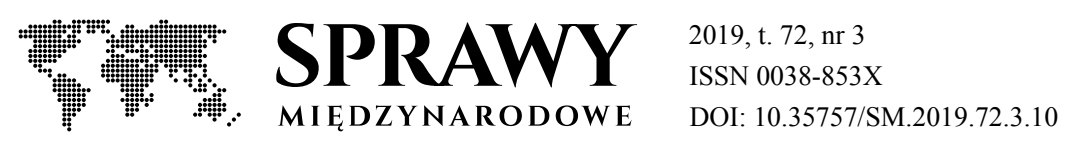

AZJA: KULTURA - EDUKACJA - SPOLECZEŃSTWO

\author{
KRZYSZTOF IWANEK
}

Akademia Sztuki Wojennej

ORCID: 0000-0002-9245-6499

\title{
Wiele przeszłości jednego narodu. \\ Nauczanie historii jako element budowy tożsamości w indyjskich podręcznikach rządowych i nacjonalistycznych
}

\section{Many pasts of one nation: history teaching as part of identity building in government and nationalist Indian textbooks}

This article compares history teaching in two types of Hindi-language textbooks used in India. One group of sources includes textbooks issued by the National Council of Educational Research and Training, a central public institution. The other one contains those published by Vidya Bharati Akhil Bharatiya Shiksha Sansthan, a network of private schools run by Hindu nationalists. The objective of this study is to analyse what political, identity-building purposes these two conflicted narratives on history reveal. Unsurprisingly, the author's conclusion is that the Hindu nationalist textbooks are biased in a number of ways. They portray India as continuously assaulted by foreign forces across the ages and united by the Hindu religious traditions. The government textbooks also stress Indian national unity at times but do not build it on the bedrock of Hindu religious traditions. While part of their contents is tilted politically to the left, they are still more balanced than the publications of Hindu nationalists. They recognise diversity much more, challenge some of the common myths and biases, admit India's various historical challenges and include perspectives of various social groups to a certain degree. The article's concluding remarks also muse on whether and in what ways such debates on Indian history affect the country's present domestic politics and foreign policy.

Keywords: India, education, history teaching, politics, Hindu nationalism

Słowa kluczowe: Indie, edukacja, nauczanie historii, polityka, hinduski nacjonalizm 
Celem niniejszego artykułu jest porównanie treści nauczania historii zawartych w dwóch rodzajach podręczników - wydawanych przez centralny rząd Republiki Indii oraz przez hinduskich nacjonalistów na użytek ich prywatnych szkół. Autor przyjmuje, że w procesie budowy tożsamości narodowej historia jest kluczowym przedmiotem szkolnym, a narracje poszczególnych podręczników mogą wskazywać na istotne różnice polityczne między podmiotami, które je wydają.

Należy przyznać, że gdy w studiach nad nauczaniem uwzględnia się jedynie tekst, a już nie to, jak w trakcie lekcji wykorzystuje go nauczyciel, uzyskuje się jedynie częściowy obraz zjawiska. Poznanie tego drugiego wymagałoby jednak bardzo szeroko zakrojonych badań terenowych, co na użytek tego studium nie było możliwe. Autor przeprowadził wywiady w szkołach hinduskich nacjonalistów, ale nie udało się tego zrobić w szkołach rządowych. Ponadto wywiadom i obserwacjom ze szkół nie towarzyszył udział w lekcjach historii, ponieważ zewnętrznemu obserwatorowi trudno uzyskać dostęp do zajęć prowadzonych przez nacjonalistów ${ }^{1}$.

Przedmiotem badań są tu zatem elementy programu nauczania (curriculum), a nie jego realizacja (curriculum transaction). Jest to wybór o tyle uzasadniony, że skupiono się na politycznych celach podmiotów stojących za publikacją podręczników, bardzo dobrze widocznych właśnie w analizie porównawczej tekstów. Niniejszy artykuł nie ma na celu odpowiadać na pytanie, jak te cele realizowane są w praktyce, gdyż zawsze zależy to od wybranego przypadku. W pewnym zakresie takie działanie badawcze można konfrontować z porównywaniem programów wyborczych partii. Ponadto tekst nie skupia się na historii jako dziedzinie naukowej ani na ustalaniu faktów historycznych, ale na obserwacji, w jaki sposób historia jako przedmiot nauczany w indyjskich szkołach przysłuża się ideologii. Autor zadaje sobie jednak pytanie, czy tego typu procesy i spory o historię wpływają w jakikolwiek sposób na politykę zagraniczną Indii.

1 O ile autorowi wiadomo, jedyną niezależną od nacjonalistów badaczką, która miała możliwość obserwowania lekcji w nacjonalistycznej hinduskiej szkole, była Peggy Froerer. Jej studium jest zresztą jednym z najbardziej wartościowych badań tego typu placówek. Por. P. Froerer, Disciplining the saffron way. Moral education and the Hindu Rashtra, „Modern Asian Studies” 2007, vol. 41, part 5, s. 1033-1071. 
Wiele przeszłości jednego narodu. Nauczanie historii jako element budowy tożsamości...

\section{System edukacyjny Republiki Indii a krajowe spory historyczne}

Za źródła posłużą podręczniki centralnej organizacji rządowej National Council of Educational Research and Training (Rāṣtrīy Śaikșik Anusandhān aur Praśikṣan Parișād, dalej: NCERT), skonfrontowane z publikacjami wydawanym przez sieć prywatnych szkół hinduskich nacjonalistów prowadzonych przez organizację Vidya Bharati Akhil Bharatiya Shiksha Sansthan.

W Indiach oficjalne szkoły mogą funkcjonować jako: prywatne, prywatne ze wsparciem rządowym i rządowe. Republika Indii jest federacją, a edukacja szkolna należy do wspólnych kompetencji rządów centralnego i stano$w_{c h}^{2}$. Szkoły rządowe mogą zatem podlegać instytucjom rządu stanowego albo centralnego. Na poziomie odpowiadającym polskiemu liceum (klasy VIXII) szkoła rządowa może wykorzystywać podręczniki zatwierdzone przez stanową radę ds. edukacji (state education board) albo radę centralną (Central Board of Secondary Education, CBSE), w zależności od tego, przy której radzie dana placówka się afiliuje. W wypadku CBSE szkoła stosuje u siebie podręczniki NCERT ${ }^{3}$. Publikacje rządowe można też przyjąć w szkole prywatnej, jeśli afiliuje się ona przy radzie stanowej lub centralnej. W uproszczeniu oznacza to, że prywatna szkoła w Indiach może stosować podręczniki wydawcy prywatnego, rady stanowej albo rady centralnej. W przypadku nauczania historii różnice między tymi trzema typami publikacji mogą być znaczące.

Ponieważ jednak edukacja należy do kompetencji wspólnych, a w razie sporu ostateczny głos ma rząd centralny, władze w Nowym Delhi mają możliwość dokonania przeglądu nauczania w szkołach prywatnych i stanowych. Jeśli uznają je za znacznie odbiegające od przyjętych zasad, mogą wymusić konkretne zmiany. Potencjalnie więc polityka edukacyjna rządu centralnego może zawsze przekładać się na nauczanie prywatne i stanowe.

Dodajmy do tego jeszcze, że od około trzydziestu lat w demokratycznych Indiach nie ma już dominacji jednej partii na poziomie centralnym (choć niewykluczone, że właśnie się to zmienia). Każdy z 28 stanów ma swój rząd i zgromadzenie ustawodawcze, których pięcioletnia kadencja często nie

2 Oznacza to, że wpisana jest na Concurrent list w konstytucji Republiki Indii, gdzie wymienia się te dziedziny, o których decydować mogą i władze stanowe, i centralne. Por. The constitution of India. Schedules, s. 326-329, dostępna w internecie [dostęp: 30 IX 2019]: <https://www.india.gov.in/sites/upload_files/npi/files/coi-eng-schedules_1-12.pdf $>$.

3 V. Lal, The history of history. Politics and scholarship in modern India, Oxford University Press, New Delhi 2006, s. 107. 
pokrywa się z kadencją rządu centralnego. W wielu z nich główną siłę stanowią partie regionalne, które niczym potężni zasiedziali magnaci często nie ulegają partii lub koalicji dzierżącej akurat stery w Nowym Delhi. Oznacza to, że również edukacja jest obszarem, w którym zawsze może dojść do konfliktu politycznego, ale przynajmniej odnośnie do nauczania historii nie każda partia czy koalicja decyduje się na szeroką reformę po dojściu do władzy. Niemniej jednak to właśnie nauczanie tego przedmiotu najczęściej jest przyczyną sporów politycznych. Od powstania niepodległych Indii kontrowersje związane z podręcznikami do historii pojawiały się najczęściej w dwóch sytuacjach: gdy dochodziło do zmiany władzy i nowa partia lub koalicja podejmowała próbę zmiany dotychczasowej narracji albo gdy rząd centralny dokonywał rewizji nauczania w szkołach na poziomie stanowym lub placówkach prywatnych i odnajdywał istotne ideologiczne różnice między ich narracjami historycznymi a własną.

Wcześniejsze spory na tym tle, szczególnie z lat 1977-1979 i 1999-2004, były już niejednokrotnie opisywane ${ }^{4}$. Znacznie mniej miejsca poświęcono kolejnemu okresowi, rozciągającemu się od 2004 do 2019 r. Mimo zmiany na szczytach władzy i w treści podręczników nie zaistniały wówczas w strefie publicznej żadne większe kontrowersje polityczne co do nauczania historii (i zapewne dlatego okres ten nie wzbudził takiego zainteresowania dziennikarzy i naukowców). Należy jednak zaznaczyć, że i w tym czasie podręczniki wydawane przez różne podmioty diametralnie różniły się od siebie, dlatego też niniejszy tekst skupi się tylko na tym okresie.

Kontrowersje na tle nauczania historii występują w Indiach co najmniej od XIX w. Od tamtego czasu ich przedmiotem bardzo często jest też religia, będąca wszak jednym z najważniejszych składników tożsamości wpólnot i ważnym czynnikiem mobilizacji politycznej. Dodajmy do tego oczywisty fakt, że indyjskie społeczeństwo jest bardzo zróżnicowane pod względem religijnym, językowym, etnicznym i kastowym. Zapewne dla każdej wspólnoty jej historia (lub mity, które jednak wspólnota uważa za historię) jest źródłem dumy i elementem tożsamości. Każdy podmiot, który chce nauczać historii

4 Przedstawiono je m.in. w następujących publikacjach: V. Lal, The history of history...; Communalisation of education. The history textbooks controversy, Delhi Historians' Group, New Delhi 2001; Against communalisation of education, Safdar Hashmi Memorial Trust, New Delhi 2002. Zob. także: L. T. Flåten, Hindu nationalism, history and identity in India. Narrating a Hindu past under the BJP, Routledge, Abdingdon 2017; S. Guichard, The construction of history and nationalism in India. Textbooks, controversies and politics, Routledge, New York 2010. 
w szerszym zakresie niż tylko w ramach bardzo wąsko rozumianej grupy, musi więc odwoływać się do szerzej pojętej tożsamości (jak naród indyjski, naród hinduski czy wspólnota muzułmańska). Tożsamość wspólnot jest więc jednym z najistotniejszych elementów funkcjonowania Indii, ale $\mathrm{z}$ drugiej strony wydaje się, że jednoczenie społeczeństwa wymaga, by państwowe nauczanie historii zostało ujęte bardziej spójnie, co prowadzi do nieuniknionego ujednolicania i generalizowania różnorodnych tożsamości lokalnych.

Wizje tego, jak i na ile należy spajać obywateli, są różne. Na poziomie centralnym od około trzydziestu lat toczy się rywalizacja dwóch wielkich koalicji: zasadniczo centrolewicowej United Progressive Alliance (dalej: UPA), na czele której stoi Indyjski Kongres Narodowy (dalej: Kongres), oraz National Democratic Alliance (dalej: NDA), która skupia niezwiązane bliżej ideologicznie partie z przewodnią rolą nacjonalistycznej hinduskiej Indyjskiej Partii Ludowej (Bharatiya Janata Party - BJP).

Promowane przez Kongres i BJP wizje spajania narodu poprzez historię są po części sprzeczne. W bardzo dużym uproszczeniu można powiedzieć, że pierwszemu z tych ugrupowań bliższa jest bardziej świecka wizja narodu indyjskiego, traktująca wszystkie wspólnoty, w tym mniejszości religijne, jako jego równych członków na bazie samego ich obywatelstwa. Za BJP stoi zaś nacjonalistyczna hinduska organizacja Narodowy Związek Ochotników (Rashtriya Swayamsevak Sangh - RSS), która głosi istnienie narodu hinduskiego połączonego więzami hinduskich (hinduistycznych) tradycji religijnych. Zgodnie z poglądami wygłoszonymi niegdyś przez ojca hinduskiego nacjonalizmu Vinayaka Damodara Savarkara indyjscy muzułmanie i chrześcijanie mogą powrócić na łono narodu, jeśli bedą traktować Indie jako swoją ziemię świętą, zaakceptują wspólną hinduską kulturę i odrzucą swój religijny radykalizm5. Choć więc na papierze ideologia hinduskiego nacjonalizmu prezentuje się jako tolerancyjna, otwarta i szersza niż hinduizm, to w rzeczywistości jest światopoglądem radykalnym, który służy głównie politycznemu jednoczeniu hindusów (hinduistów) przeciw mniejszościom religijnym i obcym siłom.

Powyższe podsumowanie jest oczywiście pewnym uproszczeniem: otwarcie politycy BJP częściej mówią o narodzie indyjskim niż hinduskim i podkreślają, że przynależą do niego także mniejszości. Równocześnie jednak większość z nich należy także do RSS i często w praktyce realizuje cele hinduskiego nacjonalizmu. Z kolei niektórzy przedstawiciele Kongresu okazywali się historycznie bliżsi poglądom hinduskich nacjonalistów lub okresowo

5 V.D. Savarkar, Hindutva. Who is a Hindu?, Hindi Sahitya Sadan, Delhi 2005, s. 100-101. 
stosowali zagrania typowe dla BJP i RSS. Idee indyjskiego narodu i hinduskiego narodu nie są zatem ściśle opisanymi ideologiami ani szczegółowymi projektami; to raczej bardzo ogólne pojęcia, dwa krańce politycznego spektrum. Posiłkując się jedynie wypowiedziami polityków czy programami wyborczymi, trudno byłoby wskazać na konkretne różnice między nimi. Lepiej widać je w wydawanych przez oba obozy podręcznikach historycznych.

Kongres dominował $\mathrm{w}$ indyjskiej polityce przez około trzydzieści lat (od roku 1951 do końca lat osiemdziesiątych). Promował wówczas swoją wizję historii - a także sam siebie - poprzez aparat państwa, w tym podręczniki szkolne. BJP i jej poprzedniczka (partia Bharatiya Jana Sangh) przez większość XX w. była natomiast siłą opozycyjną, stąd też hinduscy nacjonaliści rozwinęli własne metody szerzenia swojego światopoglądu. Jedną z nich są szkoły. RSS tworzyło swoje pierwsze prywatne szkoły już w latach trzydziestych i czterdziestych, ale większego tempa nabrało to bliżej kolejnej dekady. W latach siedemdziesiątych funkcjonowało już kilkaset szkół ${ }^{6}$, które połączono wówczas pod egidą jednej organizacji-Ogólnoindyjskiego Instytutu Edukacji „Głos Wiedzy” (Vidya Bharati Akhil Bharatiya Shiksha Sansthan, dalej: Głos Wiedzy). W następnych dekadach rozwijała się ona bardzo prężnie, m.in. przy wsparciu BJP, i nie były tego w stanie powstrzymać rządy Kongresu, choć w 1992, 1993 i 1996 r. instytucje państwowe zwracały uwagę na radykalne treści przekazywane dzieciom w szkołach Głosu Wiedzy. W momencie pisania tych słów Głos Wiedzy utrzymuje, że jest największą prywatną organizacją edukacyjną $\mathrm{w}$ Indiach, prowadzącą ponad 13 tys. formalnych szkół, w których uczą się ponad $3 \mathrm{mln}$ dzieci. Jeśli te dane są prawdziwe, to oznacza, że mniej więcej co setny uczeń w Indiach uczęszcza obecnie do szkoły hinduskich nacjonalistów.

Najsilniej obecność Głosu Wiedzy widoczna jest w północnych Indiach, na obszarze języka hindi. Większość należących do organizacji szkół znajduje się w stanach Uttar Pradeś i Madhja Pradeś. Autor niniejszego tekstu odwiedzał niektóre z nich w latach 2009-2012 - w tych dwóch stanach, ale przede wszystkim w stanie Uttarakhand, a także w Delhi, Himaćal Pradeś

6 Ch. Jaffrelot, The Hindu nationalist movement and Indian politics, 1925 to the 1990s, Penguin, New Delhi 1999, s. 532.

7 Organizacja prowadzi bowiem także szkoły jednego nauczyciela i centra nauczania dla najuboższych dzieci, ale zalicza te dwie kategorie instytucji do szkół nieformalnych, o których faktycznym funkcjonowaniu wiadomo niewiele, np. czy stosuje się tam te same podręczniki. W związku z powyższym placówki te nie są tu rozpatrywane Zob. Formal schools, „Vidya Bharati” [online, dostęp: 30 IX 2019], dostępny w internecie: $<$ http://vidyabharti.net/schools $>$. 
i Harijanie. Od poziomu liceum szkoły Głosu Wiedzy nierzadko afiliowane są przy instytucjach państwowych i wówczas używają narzucanych przez nie rządowych podręczników. Swoją ideologię szerzą wówczas na przykład poprzez apele czy nieobiowiązkowy egzamin z dodatkowej wiedzy. Afiliacji nie podlega jednak ogromna większość szkół podstawowych Głosu Wiedzy, dzięki czemu stosowane są w nich podręczniki przygotowane przez organizację. Na obszarze języka hindi większość z tych publikacji nie jest zbyt radykalna; do wyjątków należą: podręcznik przygotowujący do pozaprogramowego egzaminu, książki do nauczania moralności oraz podręczniki do historii: Gauravśálī Bhārat. Niniejszy tekst skupi się na tych ostatnich. Przywoływane tu będą wydania z 2009 i 2011 r., ale należy je traktować jako wciąż aktualne, ponieważ w najnowszych wersjach dokonano tylko drobnych korekt i zmieniono szatę graficzną.

Wszystkie cytowane tu publikacje napisano w języku hindi (choć podręczniki NCERT mają także wersję angielską). Dla uproszczenia w dalszej części artykułu będą one opisywane następującymi skrótami: GB - Gauravśálī Bhārat ('Pełne chwały Indie'), czyli podręcznik do historii używany w IV i V klasie szkół Głosu Wiedzy (co najmniej w stanach Uttarakhand i Uttar Pradeś) $)^{8}$; HA - Hamāre Atīt ('Nasze przeszłości'), czyli wydawany przez NCERT pomocniczy podręcznik do historii Indii dla klas IV-IX.

Należy podkreślić, że choć wcześniej Głos Wiedzy był atakowany a jego obecne podręczniki są po części radykalne ideologicznie - to ostatnie rządy UPA przez dziesięć lat (2004-2014) nie uczyniły niemal nic, by ukrócić działalność szkół hinduskich nacjonalistów, a podręcznik GB był w użyciu wtedy i jest teraz'. Podczas pierwszej kadencji UPA (2004-2009) NCERT wydał nowe podręczniki do historii, chcąc zastąpić nimi kontrowersyjne publikacje z czasów pierwszej kadencji NDA (1999-2004). W 2014 r. do władzy powróciło co prawda NDA, ale jej politycy nie zdecydowali się na ponowną zmianę podręczników. Porównanie publikacji wydanych przez NCERT w 2018 r. z tymi, które ukazały się w latach 2009-2011, pozwala stwierdzić, że zmiany dokonane po powrocie do władzy hinduskich

8 Więcej na temat tego podręcznika: K. Iwanek, The textbook of Chanakya's pupils. Vidya Bharati and its Gauravśālī Bhārat textbook in Uttarakhand, „Archiv Orientální” 2015, vol. 83, No. 2, s. 255-280.

9 Znajduje to potwierdzenie na stronie jednego z wydawnictw Głosu Wiedzy: Hind $\bar{\imath}$ Mìdiyam Kors ['Program nauczania w języku hindi'], „Saraswati Shishu Mandir Prakashan" [online, dostęp: 30 IX 2019], dostępny w internecie: <http://www.saraswatismp. com/mathura-region.php>. 
nacjonalistów są w większości kosmetyczne, redakcyjne i zasadniczo nie doszło do przesunięcia akcentów ideologicznych. Paradoksalnie zatem porównano tu podręcznik hinduskich nacjonalistów, który był ignorowany przez dziesięć lat rządów centrolewicowej koalicji, oraz książki wydane przez ten ostatni obóz, których nie zmieniono przez pięć lat rządów hinduskich nacjonalistów. W niczym nie zmienia to jednak zawartych w nich treści politycznych, które w przyszłości mogą stać się obiektem sporów.

\section{Dwie wizje jednego narodu. Porównanie narracji podręczników Gauravśálī Bhārat i Hamāre Atīt}

Jedną z kluczowych idei zawartych w GB jest wieczna jedność Indii. Azja Południowa jawi się tu jako jedno państwo, które przez wieki tylko od czasu do czasu rozpadało się, a potem na powrót integrowane było przez silnych monarchów. Druga część GB stwierdza, że jedność Indii jest bardzo stara, a wszyscy Indusi razem walczyli przeciw obcym najeźdźcom ${ }^{10}$. Można zakładać, że autorzy podręcznika rzutują swoje postrzeganie obecnej Republiki Indii na przeszłość. Współistnienie mnogich indyjskich królestw oraz toczone między nimi wojny prawie wcale nie są tu wspominane. Trudno zatem zrozumieć, kto i w jakim okresie panował nad danym obszarem; podręcznik nie zawiera tak podstawowych treści jak mapy $\mathrm{z}$ orientacyjnymi granicami, tabelki czy osie chronologiczne.

W GB czytamy, że podbijający Azję Południową Aleksander Macedoński musiał się zmierzyć ze zjednoczonymi Indiami ${ }^{11}$, a równocześnie opisane zostało jego starcie z królestwem Magadhy. Po stronie Aleksandra staje przeciw pobratymcom zdradziecki król Parwataka ${ }^{12}$, ale autorzy nie wyjaśniają, jak mógł być on odrębnym władcą, skoro Indie miały być zjednoczone. W rzeczywistości Magadha nie obejmowała całych Indii, a najpewniej nie była nawet w konflikcie z Aleksandrem, który nie dotarł do jej ziem. Jedyne, co w podręcznikowym opisie zgadza się z historią, to fakt, że król, którego greckie źródła nazywały Porusem bądź Porosem (GB podaje, że w sanskrycie nosił imię Parwataka), został zwasalizowany przez macedońskiego zdobywcę

10 T. Sethī, J. Negīe Rājbahādur, D.K. Simhh, Gauravśālī Bhārat. Bhāg 2. Kaksā pañcam ['Pełne chwały Indie. Część 2. Klasa piąta'], Sarasvatī Śiśu Mandir Prakāśan, Mathurā 2008, s. 75.

11 Gauravśálī Bhārat. Bhāg 1. Kakṣā caturth ke liye ['Pełne chwały Indie. Część 1. Klasa czwarta'], Sarasvatī Śiśu Mandir Prakāśan, Mathurā 2009, s. 17.

12 Tamże, s. 21. 
po przegraniu z nim walki. Kilka stron dalej czytamy jednak, że w późniejszym okresie król Magadhy Aśoka podbił Kalingę i Kaszmir ${ }^{13}$. Czy w takim razie nie były one częścią tych rzekomo zjednoczonych Indii podczas najazdu Aleksandra? Do tego momentu podręcznik nie wspominał tych regionów ani słowem, więc wyłącznie na podstawie jego treści trudno byłoby czytelnikowi uporządkować te informacje.

Jeszcze ważniejsze jest jednak, jak podręcznik przedstawia podbijanie Kalingi i Kaszmiru. Kluczowym elementem narracji GB jest założenie, że tylko hinduskie królestwa mogły jednoczyć Indie. Innymi słowy za indyjskie uznawane są tylko te królestwa, które rządzone były przez monarchów wyznających hinduskie tradycje, a ich ekspansja traktowana jest jako jednoczenie Indii; w każdym innym wypadku jest to podbój i agresja obcych sił. Po raz kolejny można zakładać, że zachodzi tu rzutowanie wizji współczesnych Indii na przeszłość - według nacjonalistów tylko władza reprezentująca hinduską religię może utrzymać kraj w jedności.

Walka z Aleksandrem koloryzowana jest tak bardzo, że jawi się niemal jako epicki bój dobra ze złem. Macedoński monarcha przedstawiony został jako człowiek chory z ambicji, który nocami śnił o podboju Indii i zapił się na śmierć z żalu, gdy tego celu nie zrealizowa ${ }^{14}$. Przede wszystkim jednak współpraca z Aleksandrem przedstawiana jest jako zdrada, a obrona przed nim - jako patriotyzm ${ }^{15}$. Podobnego wartościowania nie ma jednak przy informacji o podboju Kalingi i Kaszmiru przez Aśokę - ta informacja skonstatowana została zupełnie neutralnie. Analogicznie Portugalczycy i Anglicy czy Brytyjczycy przedstawieni są jako źli najeźdźcy, ale ekspedycja wojenna południowoindyjskiego monarchy Radźendry I Ćoli na państwo Śriwidźaja w Azji Południowo-Wschodniej chwalona jest jako zwiększająca chwałę Indii ${ }^{16}$.

Gdy mowa o innym najeździe greckim na Indie (pod wodzą Menandra), w podręczniku stwierdza się, że dotarł on do miejscowości Ajodhja, uważanej za miejsce narodzin boga Ramy. Miało to zmobilizować Indusów z różnych części kraju (w tym południa) do wspólnej obrony ziemi tego bóstwa ${ }^{17}$. Poza faktem najazdu Menandra nic jednak nie odpowiada w tym opisie ustaleniom historyków: nie ma dowodów, by jego armia dotarła do Ajodhji, a nawet gdyby tak było, to brak archeologicznych podstaw, by sądzić, ze w II w. p.n.e.

13 Tamże, s. 25.

14 Tamże, s. 18.

15 Tamże, s. 21.

16 Tamże, s. 41.

17 Tamże, s. 27. 
znajdowały się tam obiekty kultu Ramy. Słowa o mobilizacji południowych Indii ponownie wprawiają czytelnika w konfuzję. Nie ma dowodu, by wspomniane tu regiony Kalinga i Andhra wojowały z Menandrem, ale przede wszystkim znowu brakuje jakiegokolwiek wyjaśnienia, czy i w jaki sposób Indie podzielone były na różne byty polityczne, a w związku $\mathrm{z}$ tym w jakiej roli regiony te miałyby brać udział w wojnie (historycznie wiadomo, że Kalinga, Andhra i okolice Ajodhji nie należały w tym czasie do jednego królestwa). Ponownie jednak najważniejszy wydaje się przekaz ideowy: to atak na miejsce narodzin boga Ramy - twierdzi podręcznik - zmobilizował rozmaite i odległe regiony Indii do wspólnej walki z obcym wrogiem. Trudno nie postrzegać tego fałszywego opisu historii jako kolejnej paraleli do współczesności. W miejscowości Ajodhja stoi szesnastowieczny meczet Babura, który według hinduskich nacjonalistów zbudowany został w miejscu narodzin Ramy, po zburzeniu świątyni upamiętniającej to wydarzenie. W latach osiemdziesiątych XX w. hinduscy nacjonaliści uruchomili kampanię na rzecz „uwolnienia ziemi narodzin boga Ramy" w Ajodhji, to jest zburzenia meczetu i odbudowy świątyni. W 1992 r. bezprawnie zniszczyli meczet, ale świątyni nie odbudowano po dziś dzień. Kiedy zatem podręcznik umieszcza w II w. p.n.e. fikcyjną historę o wspólnej obronie ziemi boga Ramy przed obcym najeźdźcą, to zabieg ten może służyć uzasadnieniu ich działań w XX stuleciu. Narracja ta przesłania fakt, że do dziś nie ma dowodu, by w miejscu meczetu stała świątynia, i przedstawia współczesną inicjatywę polityczną jako element toczącego się od tysiącleci konfliktu w obronie hinduskiej religii.

Podręczniki NCERT również nie przedstawiają wszystkich bytów politycznych Indii i ich wzajemnych walk w sposób wyczerpujący, ale też trzeba stwierdzić, że nie byłoby to możliwe. $Z$ książek tych jasno wynika, że na przestrzeni dziejów w Azji Południowej funkcjonowało wiele państw i że nierzadko walczyły one ze sobą ${ }^{18}$. O ile GB przedstawia powstanie sipajów przeciw władzy brytyjskiej (1857-1858) tak, jakby brały w nim udział całe Indie ${ }^{19}$, to z HA jasno wynika, że rozgrywało się ono w konkretnych częściach kraju ${ }^{20}$. HA zwraca ponadto uwagę, że południowoazjatyccy władcy podczas prowadzonych

18 Por. np. Hamāre Atīt. I. Kakșā 6 ke lie itihās kī sahāyakpustak ['Nasze przeszłości. I. Pomocniczy podręcznik do historii dla klasy VI'], Rāṣtrīy Śaikṣik Anusandhān aur Praśikșan Parișād, Dillī 2007, s. 57, 112-113.

19 T. Sethī, J. Negīi, Rājbahādur, D.K. Simh, Gauravśälī Bhārat.., s. 9-12.

20 Hamāre Atīt. III. Kakṣā 8 ke lie itihās kī sahāyakpustak. Bhāg 2 ['Nasze przeszłości. III. Pomocniczy podręcznik do historii dla klasy VIII. Część 2'], Rāṣtrīy Śaikṣik Anusandhān aur Praśikṣan Parișād, Dillī 2008, s. 57, 61. 
między sobą wojen niszczyli i rabowali także wielkie świątynie, by zwiększać swoją chwałę kosztem innych ${ }^{21}$.

W odróżnieniu od narracji z GB, która przedstawia hinduską religię jako siłę jedynie pozytywną i jednoczącą, HA twierdzi również, że to hinduscy kapłani nadworni (purohici) stworzyli podział na cztery warstwy społeczne (warny ${ }^{22}$. GB wspomina je zaś tylko jednym zdaniem, pomijając fakt, że był to hierarchiczny i dziedziczny podział społeczeństwa ${ }^{23}$. W GB pisze się o czterech stadiach modelowego życia w starożytnych Indiach, ale już nie o tym, że model ten zarezerwowany był dla warstwy najwyższej - braminów ${ }^{24}$. HA zwraca uwagę, że najniższa warstwa starożytnych społeczeństw (śudrowie) nie miała prawa uczestnictwa w rytuałach i że te same restrykcje dotyczyły kobiet; niedotykalni byli zaś objęci ostracyzmem, gdyż uważano ich za rytualnie skalanych ${ }^{25}$. Kiedy zaś w GB pisano o starożytnym rytuale jadźni (ofiary dla bogów), stwierdzono jedynie, że była to ofiara dla społeczeństwa ${ }^{26}$, nie informując już natomiast, że nie całe społeczeństwo mogło w tym uczestniczyć.

W związku z powyższymi konstatacjami autor postanowił przyjrzeć się kolejnemu aspektowi narracji hinduskich nacjonalistów, tj. przedstawianiu religii hinduskiej i indyjskiego społeczeństwa jako spójnych i niemal niezmiennych. Współczesna wizja Indii i hinduizmu przenoszona jest w przeszłość. W GB sugeruje się starożytność i niezmienność hinduskich tradycji, o czym świadczą wzmianki na temat ziemi boga Ramy w II w. p.n.e. czy rozbrzmiewania w Indiach wedyjskich hymnów w czasie, gdy reszta ludzkości pozostawała dzika ${ }^{27}$ (w rzeczywistości hymny Wedy zaczęto komponować prawdopodobnie w drugim tysiącleciu p.n.e., kiedy w pewnych częściach świata funkcjonowały już inne cywilizacje). W programie szkół Głosu Wiedzy podręcznik GB poprzedzany jest ponadto dwiema publikacjami zawierającymi krótkie opowieści z Mahabharaty i Ramajany ${ }^{28}$, co sugeruje, że eposy te

21 Hamāre Atīt. II. Kakșā 7 ke lie itihās kī sahāyakpustak ['Nasze przeszłości. II. Pomocniczy podręcznik do historii dla klasy VII'], Rāṣtrīy Śaikṣik Anusandhān aur Praśikṣan Parișād, Dillī 2007, s. 65-66.

22 Hamāre Atīt. I..., s. 55.

23 Gauravśālī Bhārat. Bhāg 1.., s. 5.

24 Tamże.

25 Hamāre Atīt. I..., s. 55-56.

26 Gauravśāà Bhārat. Bhāg 1..., s. 6.

27 Tamże, s. 5.

28 Por. Mahābhārat kī kathāyẽ. Kakșā trtīy ke liye ['Historie z Mahabharaty. Dla klasy trzeciej'], Sarasvatī Śiśu Mandir Prakāśan, Mathurā 2008; Rāmāyan kī kathāyẽ. Kakṣā dvitīy ke liye ['Historie z Ramajany. Dla klasy drugiej'], Sarasvatī Śiśu Mandir Prakāśan, Mathurā 2008. 
stanowią niejako prehistorię Indii. Nie ma w nim także mowy o niemal żadnych zmianach społecznych, różnorodności religijnej poświęcono bardzo niewiele miejsca, a o zróżnicowaniu etnicznym czy językowym nie napisano nic. Wymieniając współczesne miejsca kultu w Indiach, pominięto wiele ważnych obiektów chrześcijańskich czy muzułmańskich. Podręcznik do geografii używany w szkołach Głosu Wiedzy przytacza tylko jedno muzułmańskie miejsce kultu (grobowiec sufickiego świętego Moinuddina Ćiśtiego w Adźmerze), nie wspomina natomiast żadnego chrześcijańskiego ${ }^{29}$. Mapy wykorzystywane w tych placówkach przedstawiają jedność kulturową Indii, wskazując jedynie miejsca święte dla hindusów (jak miasta czy rzeki). Owa jedność okazuje się tu więc raczej narzucaną jednolitością.

Publikacje NCERT przedstawiają to inaczej. Znacząca jest tu już sama nazwa pomocniczego podręcznika do historii - Hamāre Atīt ('nasze przeszłości'), a nie hamārā atīt ('nasza przeszłość'). Jak thumaczą autorzy, tytuł wybrano celowo, gdyż różne grupy społeczne miały swoje osobne przeszłości ${ }^{30}$. Trudno byłoby oczekiwać podobnej deklaracji w GB czy innych podręcznikach Głosu Wiedzy. Niejeden passus HA pokazuje historię z perspektywy grup nieuprzywilejowanych i tym samym wydobywa aspekty, które pomija idealizująca Indie narracja hinduskich nacjonalistów. W HA pojawiają się także faktograficzne niuanse, dzięki czemu dziejów nie da się postrzegać jako czarno-białych. Podręcznik NCERT mówi na przykład, że plemienne społeczeństwa Indii były mniej hierarchiczne niż społeczeństwa kastowe, przyznając jednocześnie, że nie oznacza to, by wszystkie aspekty życia plemion byly idealne (GB o plemionach i kastach nie wspomina niemal wcale). Można tam przeczytać, że muzułmańscy sułtani Delhi wynosili niewolników na wysokie stanowiska, a wypromowane w ten sposób osoby były wierne tylko jednemu władcy, a nie państwu, i mogły dokonać przewrotu pałacowego ${ }^{31}$. Dla autorów z obozu hinduskich nacjonalistów przedstawienie tego procesu byłoby niewygodne, ponieważ nie ukazuje on tureckich monarchów zasiadających w Delhi jako jednoznacznie złych bądź dobrych. Z jednej strony opierali swoje rządy na niewolnictwie, a ich władza była niestabilna, z drugiej jednak proces awansu społecznego na ich dworach mógł się dokonywać szybciej niż w bardziej konserwatywnych społecznościach hinduskich i obejmował również niewolników. O pozytywnych cechach państw muzułmańskich

29 Bhārat bhūmī kā bhūgol. Kakṣā pañcam hetu ['Geografia ziemi indyjskiej. Dla klasy piątej’], Sarasvatī Śiśu Mandir Prakāśan, Mathurā 2008, s. 6, 26, 29, 79, 81, 116-122.

30 Hamāre Atīt. I..., s. 6-7.

31 Hamāre Atìt. II..., s. 38. 
w Indiach podręczniki Głosu Wiedzy nie mówią w ogóle, pomijając także problem niewolnictwa na subkontynencie (choć słowo niewolnica pada w GB niejako mimochodem ${ }^{32}$ ). W HA zauważa się także, że w XIX w. pod władzą Brytyjczyków chrześcijanie otwierali w Indiach szkoły dla dzieci z najniższych kast i plemion, a wielu członków najniższych warstw społecznych wyjeżdżało do pracy kontraktowej w innych koloniach brytyjskich, aby uciec od opresji wysokokastowych właścicieli ziemskich ${ }^{33}$. GB nie wspomina o żadnych pozytywnych aspektach władzy kolonialnej, a tym bardziej o tym, że mogłaby ona oferować pewne szanse dla marginalizowanych grup, o których zresztą podręcznik ten nie mówi prawie w ogóle.

Podczas gdy GB jako dawne formuły ustroju politycznego przywołuje jedynie królestwa, HA przypomina, że w starożytnych Indiach obok monarchii funkcjonowały plemienne oligarchie, gdzie decyzje podejmowane były w gronie starszyzny ${ }^{34}$. Mówi się tam także o tym, że we wcześniejszym okresie część królów była zapewne wybierana (sanskryckie słowo rājā oznaczało z początku wojskowego przywódcę grupy, a nie dziedzicznego monarchę) $)^{35}$. Królestwo nie jawi się tu zatem jako forma władzy, która była namaszczona, by zjednoczyć całe Indie, tak jak mogłoby się wydawać przy lekturze GB.

Hinduizm przedstawiany jest $w$ podręcznikach NCERT jako religia dynamiczna i zmienna. Z niektórych fragmentów dowiadujemy się, jak stopniowo pojawiały się w niej kolejne elementy ${ }^{36}$. W odniesieniu do wieków VIIIXVIII HA stwierdza na przykład:

W tym, co teraz nazywamy religią hinduską, doszło w tym okresie do wielkich zmian. Należało do nich: wyznawanie nowych bóstw, budowa świątyń pod patronatem monarchów i rosnąca rola braminów [kapłanów hinduskich] w społeczeństwie za sprawą purohitów [kapłanów nadwornych ] ${ }^{37}$.

Tego typu poprawne opisy procesów historycznych mogą być wykorzystywane w konfrontacji z wizją dziejów, jaką propagują hinduscy nacjonaliści, uważający religię hinduską za podstawę narodu, a naród - za wieczny. Religia

32 Gauravśālī Bhārat. Bhāg 1..., s. 13.

33 Hamāre Atīt. III..., s. 114-119.

34 Nawet w tym kontekście podręcznik nie wykorzystuje jednak okazji, by stwierdzić, jak to niegdyś czyniono, że oligarchie były starożytnymi republikami lub demokracjami, które stanowiły zapowiedź przyszłej indyjskiej demokracji. Czytamy tam na przykład, że w ich radach nie mogły zasiadać kobiety czy niewolnicy. Hamāre Atīt. I..., s. 61 .

35 Tamże, s. 46, 54.

36 Tamże, s. 107.

37 Hamāre Atīt. II..., s. 11. 
ta musi być zatem równie wieczna, ale ponieważ chodzi o naród współczesny, to współczesne elementy religijne przenoszone są w starożytność, jakby za pomocą wehikułu czasu. Częstym składnikiem wizji dawnych Indii kreślonej przez RSS jest kraj świątyń, świętych (czyli kapłanów) i kultu bogów, których w rzeczywistości zaczęto czcić później (jak Kryszna czy Rama). Takie cytaty z podręczników NCERT, jak przytoczony powyżej, uderzają w tego typu narracje.

Religijny fundament tożsamości narodowej bardzo często podkreślany jest w narracji hinduskich nacjonalistów, m.in. w rozmaitych publikacjach RSS, podręcznikach Głosu Wiedzy, ale także w sposobie funkcjonowania prowadzonych przez nią szkół. Hinduskie akcenty religijne pojawiają się na przykład podczas porannych i kończących lekcje apeli, a także w formie modlitwy przed posiłkiem. Istota tożsamości narodu przedstawiana jest za pomocą symboliki religijnej, np. map świętych miejsc albo postaci bogini Matki Indii, której uczniowie oddają cześć każdego ranka. Niektóre podręczniki NCERT opisują tymczasem historyczny proces budowania indyjskiej tożsamości narodowej przez niektórych polityków w oparciu o symbole religijne ${ }^{38}$. Czyniąc to, dekonstruują przekaz nacjonalistów, ponieważ zwracają uwagę, że naród nie wyrósł na religii, a tylko politycy zdecydowali się to tak przedstawić. Co więcej, HA mówi wprost, że poczucie wspólnej tożsamości narodowej pojawiło się wśród Indusów dopiero w drugiej połowie XIX w. ${ }^{39}$

$\mathrm{W}$ narracji hinduskich nacjonalistów religia zdaje się podstawowym czynnikiem motywującym ludzkie działania. Niektórzy obcy wrogowie (np. Brytyjczycy) przedstawieni są tak, jakby religia była jednym z najważniejszych powodów ich agresywnych działań wobec Indii (co nie zawsze musi być konstatacją błędną), podczas gdy siłą kierującą mieszkańcami Indii ma być hinduizm. Przykładem jest choćby wspomniana już dwukrotnie obrona ziemi boga Ramy. Ponadto w drugiej części podręcznika GB, gdy mowa o powstaniu sipajów (1857-1858), kilkakrotnie podkreśla się, że na bunty Indusów przeciwko brytyjskiej władzy wpływały czynniki religijne: chrześcijański prozelityzm, nawracanie siłą, restrykcje religijne (np. zakaz noszenia turbanów przez żołnierzy), nakaz używania opakowań z pociskami pokrytymi tłuszczem krów i świń (pierwsze są święte dla hindusów, a drugie nieczyste dla muzułmanów ${ }^{40}$. Nie są to zarzuty fałszywe, ale ich lista skonstruowana została selektywnie i miejscami autorzy podręcznika wyolbrzymiają

38 Hamāre Atīt. III..., s. 71-73.

39 Tamże, s. 142.

40 T. Sethī, J. Negī, Rājbahādur, D.K. Sim̄, Gauravśālī Bhārat.., s. 9-10. 
problem, by uczynić z chrześcijaństwa kość niezgody między brytyjską władzą a indyjskimi poddanymi. Zakaz noszenia turbanów miał znaczenie podczas powstania indyjskich żołnierzy w Welurze w 1806 r., a nie w powstaniu sipajów. Nawracania nie dokonywano siłą (zazwyczaj zresztą robiono to niezależnie od rządu), ale faktycznie musiał to być istotny czynnik, skoro podczas powstania sipajów niszczono również kościoły ${ }^{41}$. Autorzy wydają się ponadto sprowadzać powstanie do konfliktu hindusko-chrześcijańskiego, pomijając cały wątek muzułmańskiego niezadowolenia z brytyjskiej władzy. Zamieścili jednak przynajmniej w podręczniku wzmiankę, że powstańcy uczynili swoim nominalnym przywódcą mogolskiego (a zatem muzułmańskiego) cesarza Bahadura Szaha Zafara ${ }^{42}$. HA przedstawia powstanie w sposób bardziej wyważony, nie kładąc nacisku jedynie na elementy religijne; zwraca się tam także uwagę, że w wyniku wyboru tego cesarza brytyjska władza uznała wspólnotę muzułmańską za jedno z największych zagrożeń ${ }^{43}$.

O ile podręczniki nacjonalistyczne przesycają swoją wizję dziejów religią, to publikacje NCERT czasem zbytnio bagatelizują jej rolę. Jeden z najbardziej znanych sporów historycznych, w których hinduska prawica i świecka lewica zajmują skrajne stanowiska i które stanowią papierek lakmusowy ich postrzegania historii, dotyczy najazdów tureckiego władcy Mahmuda z Ghazni na początku XI w. ${ }^{44}$ Rabował on m.in. świątynie, a w niektórych wypadkach widać, że były one głównym celem jego wypraw. Jedna $\mathrm{z}$ interpretacji zakłada zatem, że motywacją Mahmuda był islam, inna zaś, że chodziło o grabież. Faktycznie świątynie tamtych czasów akumulowały znaczne bogactwo, a niekoniecznie chroniono je tak silnie jak np. siedziby władców, stąd też stanowiły łatwy łup. Należy też jednak zauważyć, że Mahmud tytułował się ghazim (bojownikiem za wiarę) i jako sunnita dokonał także rzezi ismailitów w Sindzie. O ile to pierwsze mogło stanowić tylko retoryczne uzasadnienie dla jego grabieży, o tyle czystkę trudno traktować w kategoriach innych niż przede wszystkim religijne, ismailici są bowiem dla sunnitów heretykami. Nie można też przecież wykluczyć, że Mahmuda z Ghazni motywowały oba czynniki jednocześnie.

41 Kiedy powstanie objęło Delhi, buntownicy mieli najpierw zaatakować kościół, a dopiero potem koszary. Por. B.B. Misra, Indian middle classes, Oxford University Press, Delhi 1978, s. 101.

42 T. Sethī, J. Negī, Rājbahādur, D.K. Simh, Gauravśālī Bhārat..., s. 12.

43 Hamāre Atīt. III..., s. 57, 61.

44 Por. np. opis tej dyskusji w: R. Thapar, The Penguin history of early India. From the origins to $A D$ 1300, Penguin Books, New Delhi 2002, s. 426-432. 
GB przedstawia zniszczenie hinduskiej świątyni Somnatha przez żołnerzy Mahmuda w sposób poetycki i drastyczny: aby do niej dotrzeć, tureccy agresorzy musieli brodzić przez „stosy trupów i bagnisko krwi” powstałe po masakrze dzielnie broniących jej wiernych ${ }^{45}$. Równocześnie jednak podręcznik podaje zarówno, że turecki władca nawracał mieczem, jak i że jego wyprawy motywowane były chciwością ${ }^{46}$. HA nie opisuje najazdów Mahmuda w równie szokujący sposób, ale też z przesadną poprawnością polityczną unika poruszania kwestii motywacji religijnej. Podrozdział na ten temat nosi w tym podręczniku tytuł 'Wojna o bogactwo' i pojawia się w nim ostrożne stwierdzenie, że turecki władca „próbował zdobyć sławę, przedstawiając się jako wielki muzułmański wojownik" ${ }^{47}$.

Podręczniki NCERT zupełnie pomijają też inny bardzo kontrowersyjny temat - burzenie hinduskich świątyń przez mogolskich władców. Wspominają co prawda o trzech tego rodzaju wydarzeniach, ale w jednym przypadku chodzi o najazdy Mahmuda z Ghazni, a w pozostałych dwóch - o burzenie świątyń przez władców hinduskich ${ }^{48}$. Zupełnie pominięto natomiast przykład niszczenia świątyń hinduskich przez cesarza Aurangzeba ${ }^{49}$. Podobnie przy krótkim omówieniu zjawiska świętej wojny w imię religii podręcznik HA skupia się jedynie na przykładzie krucjat, kompletnie pomijając koncepcję dżihadu ${ }^{50}$.

Wydaje się, że zadziałał tu mechanizm wychylenia wahadła w drugą stronę: autorzy podręczników NCERT tak bardzo chcieli przeciwstawić się narracji hinduskich nacjonalistów, że w niektórych wypadkach zmarginalizowali problemy, na które tamci wskazywali słusznie. Nie ma wątpliwości, że część $\mathrm{z}$ tych autorów miała poglądy lewicowe ${ }^{51}$ i mogła myśleć o swoich publikacjach jako o odtrutce na treści szerzone przez hinduskich nacjonalistów, w rezultacie jednak w pewnych miejscach polityczna poprawność mogła przesłonić niewygodne fakty historyczne. Nie sposób także nie zauważyć, że muzułmanie stanowią część elektoratu niektórych partii z koalicji UPA, za rządów której

45 Gauravśālī Bhārat. Bhāg 1..., s. 44.

46 Tamże, s. 43-44.

47 Hamāre Atīt. II..., s. 66.

48 Tamże.

49 Więcej na ten temat zob. A. Truschke, Aurangzeb. The man and the myth, Penguin Viking, Gurgaon 2007, s. 107-108.

50 Hamāre Atīt. II..., s. 43.

51 Dobrym przykładem jest tu konstrukcja i narracja trzeciej części anonimowego podręcznika Hamāre Atīt, która budzi wiele skojarzeń z historią Indii pióra marksistowskiego indyjskiego profesora Sumita Sarkara. Por. S. Sarkar, Modern India 1885-1947, Macmillan, New Delhi 1983. 
powstały te podręczniki. Być może po prostu nie chciano zbyt ostro podkreślać antyhinduskich działań dawnych muzułmańskich władców, by nie stały się one zarzewiem kolejnych konfliktów politycznych. Po obu stronach barykady narracja historyczna jest $\mathrm{w}$ pewnym stopniu zakładnikiem podejścia do elektoratu: $\mathrm{w}$ wypadku hinduskich nacjonalistów z BJP często ma za zadanie mobilizować wyborców przeciw mniejszościom i obcym, a Kongresowi i jego sojusznikom chodzi o nieantagonizowanie mniejszości.

Kolejnym ideowym elementem narracji Głosu Wiedzy - wynikającym wprost z podkreślania spójności i niezmienności narodu indyjskiego - jest wybielanie dziejów Indii i unikanie wzmianek o podziałach społecznych, nierównościach, nietolerancji, prześladowaniach itp. GB informuje, że w starożytnych Indiach ludzie żyli po sto lat, kraj rozwijał się szybko, a edukację pobierano w szkołach (gurukulach), z których mogły korzystać również kobiety $^{52}$. W rzeczywistości gurukule były instytucjami nauczania bramińskiego, otwartymi w starożytności tylko dla kapłanów, czyli mężczyzn. W podręcznikach Głosu Wiedzy problemy społeczne i nierówności wspominane są tylko wtedy, gdy mowa jest o religijnych reformatorach czy poetach, którzy krytykowali zastane podziały i inne zasady społeczne. GB wspomina na przykład krótko, że Budda sprzeciwiał się podziałom kastowym ${ }^{53}$, ale nigdzie wcześniej ani potem nie wytłumaczono, czym te podziały były ani dlaczego Budda miałby się im sprzeciwiać. Podobnie nigdzie nie opisano w podręczniku sytuacji kobiet. Problemy społeczne pojawiają się w prowadzonej tam narracji w zasadzie jedynie jako cień wielkich ludzi: skoro bowiem autorzy GB pisali m.in. o słynnych reformatorach, to nie mogli nie wspomnieć choćby słowem o ich walce ze społecznym konserwatyzmem, ale poza tym w ogóle nie opisują tego problemu. Ponownie zupełnie inaczej wygląda to w podręcznikach rządowych, które niejednokrotnie podkreślają znacznie trudniejsze położenie kobiet, plemion i niedotykalnych $\mathrm{w}$ indyjskich społeczeństwach na przestrzeni tysiącleci.

\section{Wnioski. Nauczanie historii a krajowa i zagraniczna polityka Indii}

Przywołane tu przykłady z podręczników NCERT nie układają się w jedną, łatwą do podsumowania całość, gdyż zawarta w nich narracja jest znacznie bardziej zniuansowana od tej, którą znajdujemy w publikacjach hinduskich

52 Gauravśälī Bhārat. Bhāg 1..., s. 5, 8.

53 Tamże, s. 13. 
nacjonalistów. Autorzy Hamāre Atīt zmierzają do krzewienia patriotyzmu, ale przyznają, że w dziejach Indii obecne były nierówność społeczna i marginalizacja różnych grup. Zauważają także, że religie i tożsamość indyjska ulegały przez stulecia przemianom, a nawet przyznają, że obecna tożsamość narodu indyjskiego zaczęła się rodzić w XIX w. Do pewnego stopnia rzeczywiście jest to podręcznik przedstawiający wiele przeszłości, choć w większości nie na sposób dekonstruujący; nie podważa on jednej wspólnej przeszłości narodu indyjskiego. Jedną z jego ideologicznych wad jest natomiast unikanie niektórych trudnych kwestii, szczególnie gdy dotyczą władzy dynastii muzułmańskich.

Historyczną narrację hinduskich nacjonalistów zaprezentowaną w podręczniku Gauravśālī Bhārat (i szerzej w nauczaniu Głosu Wiedzy) można zaś streścić w następujących stwierdzeniach: (1) Starożytne Indie były złotą epoką, po której jednak (2) podlegały nieprzerwanym atakom zewnętrznych wrogów. (3) Naród indyjski jest wieczny, spójny i zjednoczony, a (4) jego podstawę stanowią hinduskie tradycje religijne, równie odwieczne i niezmienne. (5) Stąd też od starożytności naród ten nie tyle powstawał, co odzyskiwał swoją jedność po rozbijających ją okresach wrogich najazdów, (6) a co za tym idzie toczenie wojen przez hinduskich królów było uzasadnione, gdyż stanowiło element jednoczenia Indii, podczas gdy podboje innych władców były narzucaniem rządów obcych. Gdyby ekstrapolować tę wizję na współczesność (czy może raczej traktować ją jako ekstrapolację współczesnej ideologii na przeszłość), należałoby wywnioskować, że pośród kluczowych elementów działań hinduskich nacjonalistów znajdują się promowanie hinduskich tradycji religijnych, unifikowanie społeczeństwa indyjskiego i odwoływanie się do zagrożenia pochodzącego od zewnętrznych sił ${ }^{54}$. Wszystko to ma służyć budowie jedności narodowej, dla której narracja o przeszłości Indii stanowić będzie uzasadnienie.

Na koniec warto zastanowić się, czy tego typu nauczanie przekłada się na krajową i zagraniczną politykę Indii, a jeśli tak, to w jaki sposób i na ile. Jak zawsze w takich sytuacjach podstawowym problemem jest dowodzenie związków przyczynowo-skutkowych i mierzenie stopnia wpływów. Trudno nie zauważyć, że niemal każdy z elementów tej narracji łatwo wykorzystać do celów politycznych - zarówno w klasie, jak i na wiecu wyborczym.

54 Ostatni wniosek przedstawił też w swojej pracy o hinduskim nacjonalizmie Dibyesh Anand. D. Anand, Hindu nationalism in India and the politics of fear, Palgrave Macmillan, New York 2011, s. 20. 
Podkreślanie odwiecznej jedności Indii może służyć wzmacnianiu ich jedności obecnej i akurat ten cel łączy ogromną większość indyjskich partii, niezależnie od ich wizji dziejów. Skupienie się na zewnętrznych najazdach odwraca uwagę od problemów wewnętrznych, jednoczy w obliczu wspólnego wroga i kreuje zjawisko syndromu oblężonej twierdzy, które sprzyja nastrojom nacjonalistycznym. Stosując metodę projekcji, hinduscy nacjonaliści często przedstawiają jako kontynuację muzułmańskich najazdów z przeszłości Pakistan, w czym zresztą pomaga im płynąca z tego państwa narracja. Obywatele Indii mogą więc odnieść wrażenie, że obecne napięcia stanowią część trwającego setki lat boju między hinduizmem a islamem bądź między władcami hinduskimi i muzułmańskimi (i właśnie o tych stuleciach walk teksty hinduskich nacjonalistów mówią nader często). Wskazanie w dziejach Indii na monarchów, ale także jednostki i organizacje, które broniły kraju z powodów religijnych (np. chroniąc miejsca święte), pozwala uzasadniać istnienie organizacji nacjonalistycznych, jaką jest RSS, która sama właśnie tak przedstawia swoją rolę. Uzasadniana jest w ten sposób także jej niezależność działania i stosowanie przemocy, do której, jak wydają się twierdzić podręczniki, ma prawo w imię wyższego celu, jakim jest obrona państwa.

Powyższa narracja - w połączeniu z przedstawianiem religii jako głównego motoru działań ludzkich na przestrzeni wieków, a wspólnot religijnych jako monolitów - wytwarza również stan podejrzliwości wobec indyjskich mniejszości religijnych. Wzmaga się przez to stereotypowe przekonanie, że indyjscy muzułmanie bliżsi są Pakistanowi i w tej odwiecznej walce stoją po drugiej stronie (zapewne nieprzypadkowo podręcznik GB mówi o indyjskich buddystach, którzy w chwilach najazdów obcych buddyjskich władców mieli stawać po stronie agresora w imię solidarności religijnej). Pozwala to nacjonalistom jednoczyć swój hinduski elektorat przeciw Pakistanowi i krajowym mniejszościom religijnym, podczas gdy podkreślająca jedność narodu indyjskiego narracja historyczna z podręczników NCERT może być używana do jednoczenia pod wspólnym sztandarem wyborców różnych wyznań. Podkreślanie przez nacjonalistów, że tylko hinduskie królestwa mogły jednoczyć Indie, stanowi niewyrażone wprost uzasadnienie prawa BJP do rządzenia państwem. RSS zdaje się mówić poprzez podręczniki, że tak jak tylko władca podtrzymujący tradycje hinduskie mógł rządzić Indiami, bronić ich i je jednoczyć, tak tylko partia polityczna podtrzymująca te wartości teraz (w domyśle: BJP) może czynić to samo w Republice Indii.

Przeanalizowanie, czy opisywane tu procesy przekładają się na politykę zagraniczną Indii jest trudne, ale nie można wykluczyć, że tak jest, choć 
oczywiście dokonuje się to pośrednio, poprzez politykę wewnętrzną. Należy jednak dokonywać prób tego rodzaju analiz - szczególnie teraz, gdy od sześciu lat hinduscy nacjonaliści sprawują władzę w Indiach.

Po przeglądzie polityki zagranicznej Indii w latach 2014-2017 (BJP przejęła władzę w 2014 r.) autor niniejszego tekstu twierdził na łamach innego czasopisma, że ideologia hinduskiego nacjonalizmu w gruncie rzeczy nie przełożyła się na główne kierunki polityki zagranicznej Nowego Delhi w trakcie tej kadencji ${ }^{55}$. Warto jednak wskazać na bardziej aktualne i przekrojowe, bo obejmujące lata 2014-2019, badania Iana Halla, w których skupiono się na polityce zagranicznej pod kierunkiem premiera Narendry Modiego. Autor ten stwierdza, że choć podstawowe wektory polityki zagranicznej Indii nie zmieniły się, to jednak istotne znaczenie odgrywała w niej ideologia, co przejawiało się m.in. w bardziej stanowczej postawie w kwestiach bezpieczeństwa (szczególnie względem Pakistanu), kładzeniu większego nacisku na dumę narodową czy promocję kultury (np. jogi) ${ }^{56}$. Do podobnych wniosków doszli Rahul Sagar i Abhijnan Rej ${ }^{57}$. Nie sposób dowieść prostej i bezpośredniej korelacji pomiędzy wskazanymi elementami polityki zagranicznej a nauczaniem historii, ale bez wątpienia można stwierdzić, że opierają się one na podstawowych założeniach hinduskiego nacjonalizmu.

Piszący te słowa pragnie mimo to poczynić inną obserwację: choć hinduski nacjonalizm nie zmienia głównych wektorów polityki zagranicznej Nowego Delhi (gdzie ulega potrzebom Realpolitik), to jednak wpływa na nią szczególnie wtedy, gdy jest ona funkcją polityki krajowej - lub gdy polityka krajowa wpływa na zagraniczną w sposób nieunikniony (a czasem może niechciany). Dzieje się tak szczególnie w stosunkach z państwami sąsiednimi, gdyż w większości leżą one na obszarze historycznej cywilizacji indyjskiej, której dziedzictwem kulturowym tak bardzo interesują się hinduscy nacjonaliści. Podręczniki do historii mogą stanowić dodatkową podbudowę takiego myślenia o dziejach tej cywilizacji, co też dowodzi ich znaczenia dla polityki zagranicznej.

W przeszłości na przykład wiara w to, że szereg wysp i płycizn między Indiami a Sri Lanką (Most Adama, Ram Setu) jest pozostałością po moście

55 K. Iwanek, Interests before ideas. Does Hindu nationalism influence India's foreign policy?, „Acta Asiatica Varsoviensia” 2018, No. 31, s. 97-113.

56 I. Hall, Modi and the reinvention of Indian foreign policy, Bristol University Press, Bristol 2019, passim.

57 A. Rej, R. Sagar, The BJP and Indian grand strategy, [w:] The BJP in power. Indian democracy and religious nationalism, ed. M. Vaishnav, Carnegie Endowment for International Peace, April 2019, dostępny w internecie [dostęp: 22 I 2020]: <https://carnegieendowment.org/2019/04/04/bjp-and-indian-grand-strategy-pub-78686>. 
zbudowanym przez armię Ramy, sprawiła, że rząd hinduskich nacjonalistów odrzucił projekt pogłębienia tego obszaru dla ułatwienia żeglugli większym statkom. Podobnych przykładów dostarczyły ostatnie miesiące życia politycznego Indii - od sierpnia 2019 r. do chwili pisania tych słów w lutym 2020 r. Doszło w tym okresie do nasilenia projektów ideologicznych BJP i towarzyszącej ich narracji ${ }^{58}$.

Na początku sierpnia 2019 r. parlament Republiki Indii zniósł autonomię stanu Dżammu i Kaszmir, odebrał mu status stanu i wydzielił z niego region Ladakh. 9 listopada Sąd Najwyższy Indii wydał werdykt w sprawie sporu o ziemię po zburzonym meczecie w Ajodhji. Rozstrzygnięcie było bardzo korzystne dla hinduskich nacjonalistów, którzy w chwili pisania tych słów zapowiadają rychłe rozpoczęcie budowy świątyni Ramy w miejscu meczetu. W grudniu przegłosowano Citizenship amendment act (CAA), przyznający obywatelstwo uchodźcom, którzy do grudnia 2014 r. przybyli do Indii z Bangladeszu, Afganistanu i Pakistanu, ale pod warunkiem, że wyznają jakąkolwiek inną religię niż islam. Trwają również przygotowania do przeprowadzenia rejestru obywateli (National register of citizens - NRC), co budzi obawy indyjskich muzułmanów, a przede wszystkim imigrantów z Bangladeszu.

Wszystkie te działania wpisują się w szersze założenia hinduskiego nacjonalizmu (i wszystkie w ten czy inny sposób uderzają w islam lub muzułmanów), choć reformy w Kaszmirze nie można tak jednoznacznie sprowadzić do wspólnego mianownika z treścią omawianych tu podręczników do historii. Dwa pozostałe natomiast jak najbardziej wiążą się z narracją o zamierzchłych dziejach, a równocześnie jedno wpływa na politykę krajową, drugie zaś - na zagraniczną. Zbudowanie świątyni w miejscu wspomnianego meczetu w Ajodhji będzie ukoronowaniem polityki historycznej BJP i RSS. Znaczenie tej świątyni i konieczność podejmowania działań na rzecz jej odbudowy przez dziesięciolecia starano się uzasadniać w publikacjach hinduskich nacjonalistów, w tym w omawianym tu podręczniku Gauravśālì Bhārat.

Sprawy CAA i NRC, poza wywołaniem kontrowersji i protestów w kraju, mogą odegrać swoją rolę w stosunkach z Pakistanem, Afganistanem i Bangladeszem. Dotyczy to szczególnie ostatniego z tych państw, bo to z niego w ciągu ostatnich dekad napłynęło do Indii najwięcej imigrantów i już obecnie wywołuje to lekkie napięcia między Nowym Delhi a Dhaką. Zarówno

58 O przyczynach intensyfikacji tych działań właśnie w tym okresie zob. K. Iwanek, On the right track in India. The BJP's ideological drive makes perfect sense, „The Diplomat” [online], 28 I 2020 [dostęp: 23 II 2020], dostępny w internecie: <https://thediplomat.com/ 2020/01/on-the-right-track-in-india-the-bjps-ideological-drive-makes-perfect-sense/>. 
w tej sprawie, jak i w przypadku Kaszmiru rząd BJP zdecydowanie broni swoich działań na arenie międzynarodowej. Na ocenę długofalowych efektów tej polityki należy poczekać, niemniej bez wątpienia jest to przykład spójności swoistej wizji dziejów hinduskich nacjonalistów z działaniami podejmowanymi przez nich w polityce zagranicznej. Odpowiadają one narracji o stałym niebezpieczeństwie grożącym Indiom ze strony muzułmanów, a przede wszystkim postrzeganiu jednostek jako reprezentantów wspólnot religijnych, które mają definiować ich działania. Autor nie twierdzi bynajmniej, że podręczniki do historii odgrywają tu rolę kluczową, ale można dowodzić, że stanowią inny aspekt tego samego zjawiska. Trudno jednak wskazać więcej tak ewidentnych przykładów znaczącego wpływu ideologii hinduskiego nacjonalizmu na politykę zagraniczną Indii.

Debaty wokół historii i kwestii tożsamościowych mają istotne znaczenie dla polityki wewnętrznej, natomiast zazwyczaj znacznie mniejsze dla zagranicznej. W nadchodzącym czasie możemy się spodziewać nasilenia ideologicznie podbudowanych działań hinduskich nacjonalistów oraz wspierania ich przez rozmaite narracje, $w$ tym przedstawioną tu narrację historyczną, znaną m.in. z podręcznika Gauravśálī Bhārat. W dłuższej perspektywie możemy być również świadkami prób przeciwdziałania polityce RSS i BJP oraz formułowania kontrnarracji przez środowiska lewicowe i liberalne, w których zapewne znajdą się m.in. argumenty historyczne zawarte w podręcznikach NCERT. Można również zakładać, że w nadchodzących latach tego typu spory ideologiczne będą się raczej nasilać niż słabnąć, a historia pozostanie jednym z ich kluczowych elementów.

\section{Bibliografia}

Against communalisation of education, Safdar Hashmi Memorial Trust, New Delhi 2002.

Anand D., Hindu nationalism in India and the politics offear, Palgrave Macmillan, New York 2011. Bhārat bhūmī kā bhūgol. Kakșā pañcam hetu ['Geografia ziemi indyjskiej. Dla klasy piątej'], Sarasvatî Śiśu Mandir Prakāśan, Mathurā 2008.

The BJP in power. Indian democracy and religious nationalism, ed. M. Vaishnav, Carnegie Endowment for International Peace, April 2019, dostępny w internecie [dostęp: 22 I 2020]: $<$ https://carnegieendowment.org/2019/04/04/bjp-and-indian-grand-strategy-pub-78686>.

Communalisation of education. The history textbooks controversy, Delhi Historians' Group, New Delhi 2001.

The constitution of India. Schedules, dostępna w internecie [dostęp: 30 IX 2019]: <https://www. india.gov.in/sites/upload_files/npi/files/coi-eng-schedules_1-12.pdf $>$.

Flåten L.T., Hindu nationalism, history and identity in India. Narrating a Hindu past under the BJP, Routledge, Abdingdon 2017. 
Wiele przeszłości jednego narodu. Nauczanie historii jako element budowy tożsamości...

Formal schools, „Vidya Bharati” [online, dostęp: 30 IX 2019], dostępny w internecie: <http:// vidyabharti.net/schools>.

Froerer P., Disciplining the saffron way. Moral education and the Hindu Rashtra, „Modern Asian Studies" 2007, vol. 41, part 5.

Gauravśālī Bhārat. Bhāg 1. Kakșā caturth ke liye ['Pełne chwały Indie. Część 1. Klasa czwarta'], Sarasvatī Śiśu Mandir Prakāśan, Mathurā 2009.

Guichard S., The construction of history and nationalism in India. Textbooks, controversies and politics, Routledge, New York 2010.

Hall I., Modi and the reinvention of Indian foreign policy, Bristol University Press, Bristol 2019.

Hamāre Atīt. I. Kakșā 6 ke lie itihās kī sahāyakpustak ['Nasze przeszłości. I. Pomocniczy podręcznik do historii dla klasy VI'], Rāṣtrīy Śaikṣik Anusandhān aur Praśikṣan Pariṣād, Dillī 2007.

Hamāre Atīt. II. Kakșā 7 ke lie itihās kī sahāyakpustak ['Nasze przeszłości. II. Pomocniczy podręcznik do historii dla klasy VII'], Rāṣtrīy Śaikșik Anusandhān aur Praśikṣan Parișād, Dillī 2007.

Hamāre Atīt. III. Kakșā 8 ke lie itihās kī sahāyakpustak. Bhāg 2 ['Nasze przeszłości. III. Pomocniczy podręcznik do historii dla klasy VIII. Część 2'], Rāṣtrīy Śaikṣik Anusandhān aur Praśikṣan Parișād, Dillī 2008.

Hind̄̄ Mìdiyam Kors ['Program nauczania w języku hindi'], „Saraswati Shishu Mandir Prakashan" [online, dostęp: 30 IX 2019], dostępny w internecie: $<$ http://www.saraswatismp.com/mathura-region.php>.

Iwanek K., Interests before ideas. Does Hindu nationalism influence India's foreign policy?, „Acta Asiatica Varsoviensia” 2018, No. 31.

Iwanek K., On the right track in India. The BJP's ideological drive makes perfect sense, „The Diplomat" [online], 28 I 2020 [dostęp: 23 II 2020], dostępny w internecie: <https://thediplomat. com/2020/01/on-the-right-track-in-india-the-bjps-ideological-drive-makes-perfect-sense/>.

Iwanek K., The textbook of Chanakya's pupils. Vidya Bharati and its Gauravśālī Bhärat textbook in Uttarakhand, „Archiv Orientální” 2015, vol. 83, No. 2.

Jaffrelot Ch., The Hindu nationalist movement and Indian politics, 1925 to the 1990s, Penguin, New Delhi 1999.

Lal V., The history of history. Politics and scholarship in modern India, Oxford University Press, New Delhi 2006.

Mahābhārat kī kathāyẽ. Kakṣā trtīy ke liye ['Historie z Mahabharaty. Dla klasy trzeciej'], Sarasvatī Śiśu Mandir Prakāśan, Mathurā 2008.

Misra B.B., Indian middle classes, Oxford University Press, Delhi 1978.

Rāmāyan kī kathāyẽ. Kakșā dvitīy ke liye ['Historie z Ramajany. Dla klasy drugiej'], Sarasvatī Śiśu Mandir Prakāśan, Mathurā 2008.

Rej A., Sagar R., The BJP and Indian grand strategy, [w:] The BJP in power. Indian democracy and religious nationalism, ed. M. Vaishnav, Carnegie Endowment for International Peace, April 2019, dostępny w internecie [dostęp: 22 I 2020]: <https://carnegieendowment.org/2019/04/04/bjp-and-indian-grand-strategy-pub-78686>.

Sarkar S., Modern India 1885-1947, Macmillan, New Delhi 1983.

Savarkar V.D., Hindutva. Who is a Hindu?, Hindi Sahitya Sadan, Delhi 2005.

Sethī T., Negī J., Rājbahādur, Simh D.K., Gauravśālì Bhārat. Bhāg 2. Kaksā pañcam ['Pełne chwały Indie. Część 2. Klasa piąta’], Sarasvatī Śiśu Mandir Prakāśan, Mathurā 2008.

Thapar R., The Penguin history of early India. From the origins to AD 1300, Penguin Books, New Delhi 2002.

Truschke A., Aurangzeb. The man and the myth, Penguin Viking, Gurgaon 2007. 